Business Ethics Quarterly 5(1995):735-752.

\title{
ENVIRONMENTAL PROTECTION AND AN EQUITABLE INTERNATIONAL ORDER: ETHICS AFTER THE EARTH SUMMIT
}

\author{
Holmes Rolston, III
}

\begin{abstract}
The UNCED Earth Summit established two new principles of international justice: an equitable international order and protection of the environment UNCED was a significant symbol a morality play about environment and economics. Wealth is asymmetrically distributed; approximately one-fifth of the world (the G-7 nations) produces and consumes four-fifths of goods and services; four-fifths (the G-77 nations) get one-fifth. This distribution can be interpreted as both an earnings differential and as exploitation. Responses may require justice or charity, producing and sharing. Natural and national resources come into tension with the common heritage of humankind, exemplified in disputes about, who owns biodiversity resources. Ethics has to learn planetary home economics.
\end{abstract}

THE United Nations Conference on Environment and Development, the Earth Summit at Rio de Janeiro, was a watershed because from there onward two new principles of international order are indisputably in place. Nine classical principles are:

1. Sovereign equality of states

2. Territorial integrity and political independence of states

3. Equal rights and self-determination of peoples

4. Nonintervention in the internal affairs of states

5. Peaceful settlement of disputes between states

6. Abstention from the threat of .the use of force

7. Fulfillment in good faith of international obligations

8. Cooperation with other states

9. Respect for human rights and fundamental freedoms

Two new ones that solidified at Rio are:

10. An equitable international economic order

11. Protection of the environment (Jones 1991).

The nine have politics in view, but the two new ones bring economics and environment into central focus. Ten deal with culture, organizing society ethically, but in the eleventh commandment humans confront nature. Nor is it accidental that the last two appear together; they are coupled in principle and in 


\section{ROLSTON}

practice. An equitable international economic order demands environmental protection, which, in turn, is not possible without a more equitable economic order. Though nature and business are different domains, they overlap because the equitable social order demands sharing an economic productivity that has its ultimate base in natural resources. That alone makes environmental protection an ethical issue, though environmental conservation can also be an ethical issue in its own right, and not simply as connected to economic justice.

In the minds of some, international law is no law at all, because there is no one to enforce it. Admittedly, international law is soft law. One can easily enough say that nations and corporations obey it only when it suits their interests anyway. Nations predominantly act in their own self-interests, and that tends to produce weak and non-binding accords. Even binding accords are difficult to enforce without a world government. But there is another side to this. Obeying law in one's self-interests is not always to be deplored; it is typically to be encouraged. Fundamentally, we expect law sooner or later to be for our own good. And even when international law urges actors to do otherwise than they might first be inclined, though soft in one sense, this is still law with considerable power. In some sense, it is more powerful than the hard law enforced by courts, police, or the military, just because its authority is moral. Moral persuasion can move across borders where coercive authority cannot. It can persist while governments come and go.

The eleven international principles are universally agreed upon in principle, though often honored in the breach as well as in the observance. One response to these principles is to lament-perhaps also to jest—about how often they are broken. Another is to see them as norms that are powerful determinants of behavior. People break the ten commandments too, but they nevertheless are ideals that shape much behavior, more behavior than do courts, police, or military. Nations, though they may break these commandments when push comes to shove, nevertheless, reluctantly break them, and the ideal is there. They go to considerable efforts to avoid doing so; and other nations, where there are violations, readily condemn and, on occasions, introduce sanctions intended to reform behavior.

The Summit was, in essence, a morality play about environment and economics, these two new principles of international justice. We now analyze those issues.

\section{North versus South, G-7 versus G-77}

The Earth Summit was the first major international conference to take place in the post-Communist world. Throughout most of our living memory, for half a century, international affairs were oriented by the First-Second World political conflict, which had also ordered economic priorities in the industrial world. This was the first conference to explore what international confrontation is like without the Soviet polarity.

That seems, many have first thought, to leave capitalism as the only game in town, the sole economic system on the planet to be taken seriously. For many 


\section{ETHICS AFTER THE EARTH SUMMIT}

this victory is cause for rejoicing: the American way, the Western way is victorious. We have been vindicated in what we have believed all along, in the free market as the engine of prosperity, regulated if needs be by democratic process to make the playing field level and to protect certain goods of the commons. So the industrial nations, typified by the Group of 7, the G-7, at the Summit confronted the rest of the world, typified by the G-77, a coalition of developing countries (once 77 but now 128 countries). ${ }^{1}$ The agenda was no longer how capitalism and democracy could defeat totalitarian socialism, but how to get capitalism working in the Third World (for which the codeword was "sustainable development") and how to combine this with environmental protection (for which the codeword was "Earth." The issue today, in this view, is capitalizing and greening the planet.

But there have been surprises, and these became evident, even noisy, at the Summit. Suddenly it seemed, the world was full of polarities again: North/South, rich/poor, G-7/G-77 nations, developed/developing countries, overdeveloped/underdeveloped countries, overpopulation/overconsumption, powerful/powerless, justice/charity, public interest/private interests, rights/responsibilities, men in control/women without control, national sovereignty over resources/common heritage of humankind, foreign/domestic, short-term/longterm policies, present/future generations, environment/economics. Sometimes the dichotomy was even human/nature, and one form this took at Rio de Janeiro was United States/world, even, dramatically President Bush/planet Earth!

The chief of these polarities is the rich/poor divide and here the G-7 nations, with their seemingly victorious economic system, now find themselves challenged by the G-77 nations, not simply because the latter are not yet capitalists, but because, more than that, they feel themselves exploited by capitalism. The link with environmentalism is twofold: First, capitalists exploit whatever and wherever they can, both people and nature. The mentality of capitalism is consumption, and the uncontrolled escalating of consumption (symbolized by the G-7 nations) is the root problem in the environmental crisis. Secondly, the overconsumption problem in the G-7 nations is linked with the underconsumption problem in the G-77 nations, and this results in increasing environmental degradation in the G-77 nations.

The Earth Summit occurred in the five hundredth anniversary year of Columbus' discovery of the New World. The legacy of Columbus has made him a symbol of the expansion of Europe throughout the world, an era of conquest and domination achieved by both political and industrial power. But the Columbus commemoration was an uncertain celebration. North Americans, mostly of European descent, have been reared to think the settlement of the New World an impressive achievement. Europe, also in the North, was the inspiration and source of most of this; and it too has flourished in these centuries of Renaissance, Enlightenment, scientific, technological, and industrial revolution.

But the countries of the South are not so sure. In some ways they also want these goods of the modern epoch, and yet they find themselves deprived rather 


\section{ROLSTON}

than blessed by European capitalism. Most of those in the G-77 nations see themselves as the victims of colonialism. In the New World, this was, in the early centuries of the Columbian age, literal colonialism originating in the European explorations. Two years after Columbus, Portugal and Spain arrogantly divided up all of Central and South American among themselves. ${ }^{2}$ Especially in the South, the Europeans came as conquistadors. They came to exploit, nature and people, though in due course they also settled and interbred with the native peoples. Europeans also, and even more dominantly, settled the North American New World, and there almost completely evicted the indigenous Indians. Africa and Asia in the Old World have likewise been the victims of colonialism. The divisions are not so much New versus Old World as North versus South.

But is not the colonial era past? The nations of Central and South America, of Africa and Asia, in this century if not in the last, have almost every one gained their independence. They are sovereign nations, and the first four of the principles of international order guarantee this autonomy: the sovereign equality of states, territorial integrity and political independence, equal rights and self-determination of peoples, and nonintervention in the internal affairs of states. So, one might reply, let us look to the present and to the future. Colonialism is not the issue; the agenda is capitalizing and greening the Earth.

But is the colonial era really past? Though nations have their formal independence, there is a continuing economic and technological colonialism with a widening gap as the wealthy North extracts resources from the poor South. The drain continues, despite the alleged national integrities and sovereignties. In fact, because of debt repayment and trade restrictions, countries of the South transfer $\$ 200$ billion to the North each year (Knickerbocker 1992c). The result, coming to a focus in the envy and Condemnation of the G-7 nations at Rio, is that many in the G-77 nations see Northern prosperity as significantly a result of exploitation of the South.

\section{Earnings versus Exploitation}

Consider a pie diagram. This diagram should be regarded as an illustrative trope. The proportions are only representative, but one can substantiate the general picture with numbers from almost any segment of industrial productivity. All will show sharp asymmetries in demography and economics characterizing the two major blocs at the Earth Summit. The North, with about one-fifth of the world's total population of five billion persons, produces and consumes four-fifths of all goods and services each year. The South, with fourfifths of the world's people, produces and consumes only one-fifth. For every person added to the population of the North, twenty individuals are added in the South. For every dollar of economic growth per person in the South, twenty dollars accrue to each individual in the North (World Development Report 1991).

The consumption gap between industrialized and developing countries is eighteen to one for chemicals, ten to one for timber and energy, three to one for grain and fresh water. The average income of the rest of the world is below the 


\section{ETHICS AFTER THE EARTH SUMMIT}

U.S. poverty line (about $\$ 5,000$ ). The typical European country consumes ten times the energy per person of Africa; North Americans consume twenty times as much (Knickerbocker 1992c). Meanwhile too, the richest one-fifth of humanity causes vastly disproportionate environmental damage because of its growing demand for material goods.

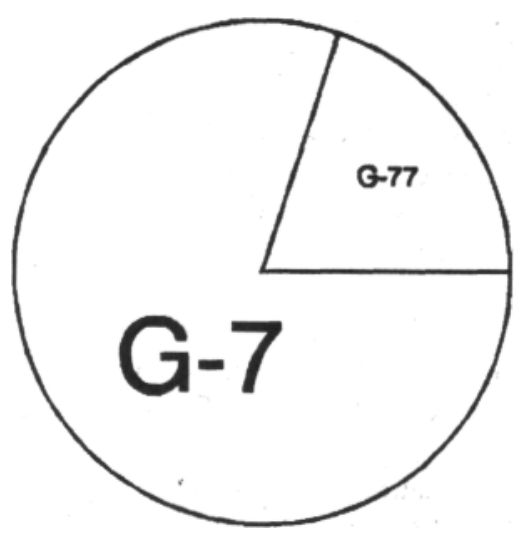

It is difficult to look at a diagram of this son and not think that something is unfair, that there is an inequitable economic order, regardless of the causes. Further, wondering about causes, it is difficult to escape the query whether the richness on one side is not at least partly related to the poverty on the other. This yields the exploitation model. If, next, we reinterpret the pie as the global Earth, the commons to be divided and conserved, it seems patently absurd for the G-7 nations to urge environmental conservation on the G-77, since it is the G-7 nations that are eating most of the pie, that is, consuming most of the natural resources on Earth. The G-77 nations hardly have enough to eat, and should the G-7 nations preach to them about protection of the environment, for the benefit of the rich?

But there is another way of viewing the pie: an earnings model. After all, pies have to be produced before they can be divided, and who has produced this pie? Who deserves the pie? Most of us believe that some people can have more merit than others. If we are academics or students, we give and earn grades on that basis. The quality points go to the performers. If we watch sports, we believe that, overall, the best teams win. If we are business persons, we reward hard work with merit pay; we reward skills achieved and employed productively with wealth. If we are laborers, we agree. The laborer is worthy of his or her hire. Some companies, well-run with good esprit de corps, have more merit than others. Contrariwise, either bad management or bad labor can ruin a business.

Everyone knows that there are exceptions, good businesses that fail; still, we think the exceptions are anomalies in a statistically reliable system. That really 


\section{ROLSTON}

is what capitalism is all about; entrepreneurs who can produce what society needs are justly rewarded; people who work hard earn good pay Checks. That is also what fairness is all about. Fairness nowhere commands rewarding all parties equally; justice is giving each his or her due. We treat equals equally; we treat unequals equitably, and that typically means unequal treatment proportionately to merit. Again, there are exceptions. But there is nothing evidently unfair in the pie diagram, not at least until we have inquired about earnings.

Can some countries have more merit than others? We have all been justifiably cautioned of ethnocentrism in the modern age, and many of us have been guilty of it. Modesty becomes us all, and one is reluctant to be too proud about success. By the time one reaches the scale of country, perhaps statistical averages take over, and every country has its mix of deserving and undeserving persons. Every country has management and labor that sometimes succeeds, sometimes fails. People are the same all over the globe, and excellence is no respecter of national * boundaries. We do not want to be discriminatory; we want to be fair.

Is that all there is to be said? For we do not want to be undiscriminating either, and it may simply be naive, and wrong, to think that one nation is as good as another. We do take considerable pride in being, say, Americans, or British, or Germans. Patriotism is sometimes a justified virtue. The Puritan work ethic has been too much complained about in this century; we are not really ashamed of it. We rather think that our forefathers got what they got by Yankee ingenuity, hard work, thrift; they built the nation, plowed the prairies, hoed the corn, split the rails, paved the roads, and on and on. There is a commendable genius in the American blend of democracy, industry, and labor; that is, in fact, what has made the United States the envy of much of the world. Similar things can be said for any and all of the G-7 nations, and the lesser ones too with a high per capita wealth. Americans have come to admire the Japanese for their hard work and industry. If one compares, say, Sweden with Uganda, the Swedes have an earned prosperity that the Ugandans lack, unfortunately. But Idi Amin Dada and his supporters did make a series of mistakes that left the country in shambles.

So one reply to the charge that Northern prosperity is stolen from the South is to reaffirm what the North has itself earned. North Americans typically do not think that their wealth has been obtained at cost to the Central or South Americans, much less the Africans or Asians. They earned it themselves. For most of its development the United States was a rather isolated nation; not much of what went on in Minnesota or Iowa was connected with anything going on in the Congo or Amazon. Perhaps we imported coffee or bananas, but we paid for what we imported. ${ }^{3}$ The real genius of America has arisen in the wheat fields of the mid-West and the factories of Detroit. We did need the Panama Canal as a shipping lane, but little or none of the poverty of Honduras or Brazil is our fault.

True, the typical U.S. citizen consumes 20 times as much energy as the typical African; but, apart from the recent global warming issue, energy consumption is not ipso facto a bad thing; it is part of the genius and blessing of industrial civilization to be able to replace muscle with motors and electricity. No one has 


\section{ETHICS AFTER THE EARTH SUMMIT}

yet demonstrably been hurt by global warming. U.S. prosperity is a good thing, evidenced by how much others would also like to enjoy it. A high standard of living is not something to apologize for; it is something to brag about. That is the genius of the scientific, technological, industrial revolution, of which the fruits can and have been reasonably well distributed within the United States, and other G-7 nations.

At the Earth Summit, the U.S. had steadily to resist the idea that the proper response to U.S, prosperity is a guilt trip, or that Third World poverty is the fault of the United States in its prosperity. That had to be done diplomatically, even if the charges were sometimes not very diplomatic. An example of this kind of debate was over proposed language in Chapter 4 of Agenda 21, "Changing Consumption Patterns," a bracketed [that is, contested] text which read "4.3. While poverty largely results in certain kinds of environmental stress, one of the most serious problems now facing the planet is that associated with historical patterns of unsustainable consumption and production, leading to environmental degradation, aggravation of poverty and imbalances in the development of coun ${ }^{\wedge}$ tries-4.5. Although consumption patterns are very high in certain parts of the world, the basic consumer needs of a large section of humanity are not being met. This inequitable distribution of income and wealth results in excessive demands and unsustainable lifestyles among the richer segments, which place immense stress to the environment. The poorer segments, meanwhile, are unable to meet food, health care, shelter and educational needs." The U.S. objected to this language, on grounds that it simplistically implied that the poverty in the South was the fault of consumption in the North, which was, indeed, the way such language was routinely being interpreted. In the Main Committee debate, the U.S. proposed alternative language, and received a barrage of criticism from Third World Nations. ${ }^{4}$

The initial reaction to the pie chart is that goods are unfairly distributed. But the United States at Rio, in particular, and in defense of the Western way of life, in general, has tried to insist: We produced the pie we eat. We earned it

\section{Justice or Charity?}

There are duties of justice and duties of benevolence. If I have wronged someone, I owe amends. Such an obligation is considerably stronger than the obligation to charity - at least in common morality, although religious moralities can increase the obligation to charity. If I have harmed you, you can take me to court. Redress is a matter of tort law. But if you are in need, through no fault of mine, and I refuse to share my wealth, no court can force me to make a donation. On the exploitation model, a redistribution of wealth, North to South, is owed to those who have been exploited as a matter of justice. On the earnings model, however laudable it might be for those with more of the pie to share, there is no issue of justice at stake, only the possibility of benevolence.

To use the language of rights, redress for the exploited is a matter of right. But aid to the poor, though right enough a thing to do, is not so mandatory. Nor is it 


\section{ROLSTON}

particularly the province of either government or business to practice charity, though both are bound by justice. We qualify this to some extent in our modern welfare states, as are most of the G-7 nations, allowing that no one ought to starve, and that the wealthy can be taxed to prevent this happening among the poor. But we are willing to make handouts only up to a threshold level; after that, the poor will have to get what they earn.

Further, a society will wisely try to elevate the education and skills of the poor; therefore the G-7 nations offer a minimal education free to all, at taxpayer expense. But this is justified because all-rich and poor alike-have an interest in a citizenry equipped with basic working skills, able to read, write, vote. Everybody gains by keeping indigents off the welfare rolls. The rich may be taxed to educate the poor, but when the poor themselves become self-supporting taxpayers, the rich gain more than they have lost. Nothing in such welfare gainsays the basic earnings models. Justice envisions that citizens will be wageearners; any benevolence that disrupts the expectation is misplaced and does more harm than good.

Moving outside national boundaries, the obligation to benevolence becomes even weaker, especially benevolence by state and business, and especially during an era of recession at home. Nations of the South want, and believe they have coming to them as a matter of justice, aid packages that nations of the North have found unacceptable, because they are more charity than justice. This was perhaps the most difficult agenda item at Rio. Again, such issues have to be argued diplomatically, in the midst of sometimes not so diplomatic charges of inequity, but this tension between justice and benevolence is never far beneath the surface. The official UN goal for development aid to poorer countries is $0.7 \%$ of GNP from industrialized countries, but only a handful (like Norway) have met that goal. The U.S. figure is nearer $0.3 \%$ and some of that is, in effect, military aid.

No theme was more repeated at the UNCED Conference than that the environment could not be saved without large amounts of aid from industrial to developing nations. Maurice Strong claimed, "The summit must establish a whole new basis for relations between rich and poor, North and South, including a concerted attack on poverty as a central priority for the 21st century" (quoted in Allen 1992). The figure for aid repeatedly given by Maurice Strong, and debated in the Agenda 21 texts, was $\$ 125$ billion a year over the next eight years (Knickerbocker 1992b). Anwar Saifullah Khan, Pakistan's environment minister, speaking on behalf of the G-77, said: "We cannot save the environment if the rich refuse to provide greater aid to the poor" (quoted in Kamm and Gutfeld 1992). Lester Brown, president of Worldwatch, agreed: "We can no longer separate the future habitability of the planet from the current distribution of wealth." ${ }^{5}$ William K. Stevens summarized the mood of the G-77: "If the South is to play the game of environmental protection, they insist, the North must pay" (Stevens 1992: 1).

In debate over contested texts in Agenda 21, for example, a proposed text read, "Additional financing resources in favor of developing countries are essential" 


\section{ETHICS AFTER THE EARTH SUMMIT}

to environmental conservation, in a context implying the obligation of developed countries to supply such resources. The U.S. proposed instead, 'The availability of additional external resources will increase as foreign entities are convinced that such resources will generate a positive result." G-77 nations protested intensely; eventually Chile proposed an acceptable text: "Additional financial resources in favour of developing countries and the efficient utilization of such resources are essential" (Sec. 2.24). ${ }^{6}$

The funds made available from G-7 to G-77 nations are loosely characterized as "aid." Are they to be thought of as justice or as charity? Or are these categories inappropriate? Perhaps they are charitable investments? Another way of asking the question is, Who benefits from this aid? To the demand for aid, G-7 nations reply that, while they are interested in making investments abroad, investments that will serve both development interests in G-77 nations and investor interests in G-7 nations, G-7 nations cannot legitimately tax their own citizens to donate monies to help the poor outside their boundaries. Such benevolence may be commendable enough for Presbyterians or for members of the Nature Conservancy, but it is no obligation of governments. Indeed, this would be wrong of governments, for it would be an illegitimate forced transfer of wealth. All that can fairly be expected of enlightened governments is participation in an equitable international order (principle 10) that protects the environment (principle 11); there is no international principle that calls for generosity.

\section{Produce or Share?}

Consider the pie chart again. There are two basic responses to the fact that the G-77 nations have only one-fifth of the pie. One response is: Produce! The other is: Share! Those who see their pie as earnings - the result of the genius of science, technology, industry, thrift, management, labor, democracy, free enterprise- see the solution as growth. Those who see exploitation, see the solution as redistribution. That much involves principle 10: an equitable economic order, revolving around the question whether the material goods of Earth are earnings equitably distributed. On another reading, the pie is the global Earth, resources that must be conserved, and that elevates concern to principle 11: environmental protection.

The official United Nations texts are often ambivalent about producing versus sharing; and, naturally enough, many diplomats tend to reply that both are needed. Still, the logic of each answer is different, and giving them both can be as inconsistent as it is complementary. Consider the conclusions of the World Commission on Environment and Development: "It is essential that global economic growth be revitalized. In practical terms, this means more rapid economic growth in both industrial and developing countries-The Commission's overall assessment is that the international economy must speed up world growth, while respecting the environmental constraints." "A five- to tenfold increase in world industrial output can be anticipated by the time world population stabilizes sometime in the next century" (UN World Commission on Environment and Development 1987b: 89, 213). That conclusion is: More pie. Produce! 


\section{ROLSTON}

This production can, at first, seem welcome enough to the G-77 nations, for whom a five- to tenfold increase seems highly desirable. But wait a minute! That will just produce bigger pie. The pie diagram will be five or ten times bigger, and the distribution patterns unchanged. The G-7 will still eat four-fifths of the pie; the G-77 nations will only eat one-fifth of the larger pie. And if one realizes that the pie is not so much earnings that can grow without limit as an Earth that is reaching its carrying capacity, it is not clear that we can enlarge the pie five or ten times. We cannot make the planet any bigger at all. If the planet is already stressed with the demands that the G-7 and G-77 nations collectively place on it, the "More pie!" response becomes part of the problem, not part of the solution.

Hence the struggle of the Third World nations to place redistribution into Agenda 21.

"Here, we will help you produce," say the G-7 nations. We will make investments in the G-77 nations. But consider the North American Free Trade Agreement Act (NAFTA), being worked out at the same time as UNCED was taking place, and since then signed by Canada, the United States, and Mexico, and subsequently authorized by the respective legislatures. The Act is designed to attract capital to Mexico. U.S. companies will move there, employ Mexican workers, and Mexico's Gross National Product will rise. Produced goods will be sold in all three countries at cheaper prices. Does not this seem like both growth and redistribution?

But appearances can be deceiving, typical wages now paid by the existing maquiladoras, U.S. industries in Mexican bordertowns, average a dollar an hour, less than one-fifth of comparable wages in the United States, and standards of environmental protection are quite lax. Working conditions are poor and the Rio Grande has become a chemical sewer, laced with toxics. Land prices drive Mexican farmers off their land. Workers, already about a half million of them, are withdrawn from Mexican businesses and farms, which cannot compete with even the dollar an hour that the American companies will pay. Mexican businesses and farms suffer. There are taxes on the American industries, but these must often be used to repay the national debt, and so these funds flow back to American banks.

The benefits principally accrue to the American owners, who make more profits, and their largely American customers who have cheaper goods. The result can in fact be exploitation again, without any real redistribution of the pie, even though there is more production. Neither principle 10, the equitable economic order, nor 11, protection of the environment, is automatically served by the NAFTA agreement. The fundamental reason is that the agreement is oriented by the imperative to produce, rather than that to share.

Gerard Piel, founder and publisher of Scientific American, can, as might be expected, amply urge accelerating the industrial revolution in those parts of the world where it is only yet beginning. But, whatever important part of the answer this is, business as usual is not an answer that we can really entertain. Concluding a study of the human place in nature, and of human relationships in culture 


\section{ETHICS AFTER THE EARTH SUMMIT}

he insists, "The economy of growth, it is now clear, must give way at last to the economy of equity" and "people must accomplish the necessary reconstruction of their values and institutions. ...This only one world is our own to make and tokeep"(Piel 1992, p. 328).

Surveys in these developed nations show that there has not been any noticeable increase in personal satisfaction or happiness (Durning 1992). We are having second thoughts about affluence and well-being. George Brown, Jr., Democrat from California, the influential chair in the U.S. Congress of the Science, Space, and Technology Committee, addressed the annual American Academy of Science and Technology Policy Colloquium:

Global leadership in science and technology has not translated into leadership in infant health, life expectancy, rates of literacy, equality of opportunity, productivity of workers, or efficiency of resource consumption. Neither has it overcome failing education systems, decaying cities, environmental degradation, unaffordable health care, and the largest national debt in history. ...Basic human needs - elemental needs - are intrinsically different from other material needs because they can be satisfied. Other needs appear to be insatiable, as the consumption patterns of the United States clearly demonstrate. ...Once basic human needs are met, satisfaction with our lives cannot be said to depend on the amount of things we acquire, use, and consume. ...More technology-based economic growth is not necessary to satisfy humanity's elemental needs, nor does more growth quench our thirst for consumption. In terms of the social contract, we justify more growth because it is supposedly the most efficient way to spread economic opportunity and social well-being. I am suggesting that this reasoning is simplistic and often specious."

The G-7 nations, by this account, are satisfying desires on an ever-escalating treadmill, without being sufficiently critical of those desires. "The urgency of wants does not diminish appreciably as more of them are satisfied," concludes John Kenneth Galbraith (1984, p. 119) of Western man, and, really they "cannot be urgent if they must be contrived for him" (p. 126). Microwave clothes dryers, now in development, are an example. Produce? This may not be the answer we want in the developed world. Meanwhile, there is the other four-fifths.

\section{Natural and National Resources}

The equitable international economic order and environmental conservation come into conflict over biodiversity and biotechnology issues. Briefly, the biodiversity to be protected typically lies in the South; the biotechnology skills are held in the North. Though a once-envisioned biotechnology convention failed at UNCED, biotechnology became a subtheme within the Convention on Biological Diversity, and misgivings about biotechnology, rather than biodiversity, were the principal reason the United States, alone among major world nations, then refused to sign the Convention. (President Clinton has since signed it, though Congress has not yet authorized it.) Once again natural resources and their just distribution are at issue, only this time the categories are those of national resources, owned by G-77 nations and peoples, versus natural resources, seen as the common heritage of human kind. 


\section{ROLSTON}

Merck Pharmaceuticals manufactures a treatment for glaucoma based on an alkaloid extracted from jaborandi, a bush found exclusively in the Amazon. Kayapo and Guajajara Indians, who first used the plant as a medicine (in a way quite unrelated to treating glaucoma), now harvest and sell the leaves to Merck under poorly paid conditions. In Germany, the alkaloid is refined and made into eyedrops which Brazil, among other countries, imports. If a Brazilian company were to produce the remedy, it would have to pay royalties to Merck to use the patented technology. Northern biotechnology companies see this as a right to earnings on their investments. Southern nations see this as more of the all-to-familiar exploitation.

No one denies that Merck ought to pay fairly for the leaves and their harvesting. The tough issues lie deeper. Who, if anyone, owns the right to use these plants? Who is and ought to be responsible for conserving them? Does Merck owe today's Indians anything because their ancestors once discovered that the plant might have other medical uses? What if Merck were to grow the plant elsewhere, or (as is not unlikely) to synthesize the alkaloid from other materials? Then they would pay the Indians nothing.

Ought Brazilian pharmaceutical companies (which are not owned by Indians) have free (or low-cost) use of the technology Merck developed in Germany? If there were any payments for the right to use the plants to whom should they go? To the federal Brazilian government? The state of Amazonas? To the Indians, tribally or personally? To those whose (unknown?) ancestors discovered possible medical uses? To those who own, or live on, lands on which the bush is now found? The bush does not grow exclusively on Indian lands. Who owns wild species anyway? If there are any owners, presumably they are the persons chiefly responsible for its protection, as well as those entitled to benefit from its economic exploitation.

The Convention on Biological Diversity begins insisting that "States have sovereign rights over their own biological resources" (Preamble) and continues, "Recognizing the sovereign rights of States over their natural resources, the authority to determine access to genetic resources rests with the national governments and is subject to national legislation" (Article 15). The Convention recognizes "patents and other intellectual property rights," but also insists that "access to and transfer of technology...to developing countries shall be provided for and/or facilitated under fair and most favorable terms" (Article 16). Signatory parties bind themselves to "sharing in a fair and equitable way the results of research and development and the benefits arising from the commercial and other utilization of genetic resources" (Article 15) (UNCED 1992a).

All that sounds right-at least at first. Such commitments would seem to produce concern for the protection of biodiversity as well as an equitable sharing of benefits gained from it. So what are the difficulties? Look more closely at questions of ownership.

Historically, wild plant species, seeds, and germplasm have long been considered in the public domain, not owned by any nation. Developing nations are now claiming ownership by the country of origin, and that these cannot be used by 


\section{ETHICS AFTER THE EARTH SUMMIT}

those in other nations without negotiated compensation. That seems fair to them. They interpret the Convention accordingly. But the developed nations take these biological resources and exploit them, not paying the owners a fair return. The Director of the Research Foundation for Science, Technology and Natural Resource Policy in Dehradun, India, Vandana Shiva complains, "The US...has engaged in unfair practices related to the use of Third World genetic resources. It has freely taken the biological diversity of the Third World to spin millions of dollars of profits, none of which have been shared with Third World Countries, the original owners of the germplasm." Shiva cites a wild tomato variety (Lycopersicon chmielewskii), first collected in 1962, that was bred into and enhanced the tomato for the U.S. industry, resulting in $\$ 8$ million a year profits, and for which Peru, the owner nation, was paid nothing. In aggregate, "the total contribution of wild germplasm to the American economy has been US \$66 billion," despite the fact that "this wild material is 'owned' by sovereign states and by local people" (Shiva 1991: 260-61).

Can natural resources be national resources? Certainly, they often can. Nonrenewable resources (ores, minerals, petroleum) are owned by the nation state in which they happen to be found, indeed by private individuals and corporations within such states. Likewise with biotic resources, if one is referring to harvested materials. Nations and individuals own the forests on their land; farmers own the crops in their fields. The G-77 nations at Rio were glad to affirm in the biodiversity convention their right to develop their national, natural resources.

But biotic resources are also less evidently subject to ownership, if one refers to the species, to the natural kinds. People, also perhaps nations, do own natural resources. But does the landowner own the vertebrate wildlife on his or her land? In some nations yes, but in many nations no. The wildlife are a commons, a trust, belonging to no one, although some persons may, at times and under appropriate conditions, take possession of wildlife, as when on a hunt Wildlife move around; they migrate from one property to another. African wildlife and the migratory birds even move from nation to nation. Plants, by contrast, are rooted to the ground, so we do often think that landowners own the plants. Nations have sovereignty over their public lands; their forests are their national resources.

If we follow this logic, we can understand the Third World complaint. Shiva continues, "Thus, the North has always used Third World germplasm as a freely available resource and treated it as valueless. The advanced capitalist nations wish to retain free access to the developing world's storehouse of genetic diversity, while the South would like to have the proprietary values of the North's industry declared a similarly 'public' good. The North, however, resists this democracy based on the logic of the market. ...There is no epistemological justification for treating some germplasm as valueless and common and other germplasm as a valuable commodity and private property" (Shiva 1991: 257-260).

Shiva is right that there is no justification for treating some germplasm as valueless, but there is a justification for treating wild germplasm as commons and manipulated germplasm as private property. There are several important epistemological differences here. One is between what we have on Earth by gift 


\section{ROLSTON}

of wild nature and what we have as a result of human labor, another is between renewable and nonrenewable such gifts, still another is between a token of a natural kind and the type itself.

One may own gold on his land, token samples of a type, but no one owns gold as a natural kind; no one owns the structure of the atom. One may own bushes of jaborandi, but does anyone own the DNA coding within it or the species as a historical line? The value of wild germplasm is not owned by the peasant farmer any more than by modern agriculturalist, nor by Third World nation any more than by First World nation. The democracy Shiva wants equates alleged ownership of wild species, and freely sharing them, with alleged ownership of agricultural and industrial patents, and freely sharing them. That misunderstands as equals what are not equals, wild species on the one hand and the products of human labor on the other; the one is a commons and the other is property. This is not, contrary to her allegations, "double standards" and "double-speak" (261); it discriminates an important difference between the biodiversity we inherit on the planet by natural history and what we achieve by our cultural labors.

We pay Arabia for oil found there, a nonrenewable resource, though we do not pay Arabia for the use of any hydrocarbon organic petroleum structures. We do not pay Afghanistan for the use of the bread wheat species (Triticum aestivum) which historically originated there, nor do we pay Mexico for the use of corn (Maize, Zea mays), nor have we paid Ecuador and Peru for tomatoes (Lycopersicon esculentum) and potatoes (Solatium tuberosum). Two of the most widely grown crops in South and Central America are bananas (Musa paradisiaca var. sapientum) and coffee (Coffea arabica). Bananas originated in Malaysia, coffee in Ethiopia.

What is the difference, in principle, between the tomatoes taken from Peru, first centuries ago and more recently in 1962, and used elsewhere, and the bananas taken from India, centuries ago, and now grown all over Central and South America, for which peoples in these nations have never and do not now pay the Asian Indians anything? Nor should they, by the common-heritage-ofhumankind argument. Chickens, raised the world over, originated as jungle fowl in Africa. If the Pacific yew tree (Taxus brevifolia), found in the U.S. Northwest and a source of taxol, proves to provide a cure for cancer, and if it can be grown in the cool climates of Argentina, will the Argentineans owe royalties to the states of Washington and Oregon, or to the United States federal government? (Perhaps we should notice that Brazilians did widely regard the rubber tree [Hevea brasiliensis] as being stolen when they were first taken to Asia and rubber plantations developed there).

Matters will be different where the germplasm is not that of wild species, but that which results from the breeding skills of farmers over generations (an argument Shiva also advances). In nations that have had, over the centuries, no patent system, ownership here will be vague, and most patents are for limited periods of time. The know-how to build a steam engine, once discovered by James Watt, is now in the public domain. But it can be consistently argued that the North overlooks the husbandry of the South over the previous years of 


\section{ETHICS AFTER THE EARTH SUMMIT}

agricultural civilization. That does equate equals in principle: the labor of the traditional farmers versus the labor of the latter-day geneticists. Meanwhile, the Peruvians were not making any use of Lycopersicon chmielewskii at all; in the wild the plant produces a small, hard, green, inedible fruit that does not even turn red; they hardly knew it was there.

We may worry that the logic of this argument comes out the wrong way for Third World peoples. We have steadily been wondering whether the G-77 peoples get their fair share of the goods of Earth, but here, when an effort is made to place value on the biodiversity that they do own, we resist that, claiming the common heritage of humankind. Meanwhile we resist too any sharing of biotechnology patents, claiming that these are investments that can demand earnings. So, with this logic, the North Americans get better tomatoes; the Peruvians get nothing. Germans profit from Merck's sales; the Amazonian Indians remain poor.

We do lament the inequitable distribution of wealth in the world, and Third World voices may be quite right that there is something unfair about it. No one wants uncritically to defend profiteering industrialists. But, it is important to get the logic right. Philosophers have to follow their logic where it leads them whether they want to go there or not. Conservation based on an unsound logic will come undone sooner or later. Surely there is a sounder logic by which fair and equitable conservation can be achieved.

The biodiversity convention, though it insists on "sovereign rights to exploit natural resources" avoids the language of ownership. It speaks instead of "access to genetic resources." That can be interpreted as ownership, but need not be. The possibility of another interpretation is one result of the subtle debates conducted over these texts. Patent holders do own what they give access to. Do nation states own the species to which they give access? Not necessarily. By contrast, landowners may control access to their property, even though they do not own the wildlife on it. Sovereign nations may control access to their territories, even though they do not own the wild species on their landscapes.

In 1991, Merck signed an agreement with the National Biodiversity Institute of Costa Rica, a national agency. The Institute is attempting to identify all wild plant species in the country, do a preliminary screening, and make agreements with pharmaceutical companies for further use of promising plants. Merck provided \$1 million over the years of 1991-1992 and gets, in return, the exclusive right to screen the collection for useful plant chemicals. The logic here is not that the Costa Ricans own the plants, but that they have the right to give or withhold "permission to collect" on their soil, and that they can be paid for this permission. In the Merck case, this money will go to fund the collection. In other cases, it could go to fund on-the-ground conservation.

Now we do begin to bring an equitable economic order under the aegis of environmental conservation, and vice versa. An agreement whereby profits of the industry using wild resources go to assure conservation of what remains makes perfectly good sense, oblivious to national boundaries, because these are global commons conservation problems and opportunities. Ownership status 


\section{ROLSTON}

and rights to exploit ought to be reconceived as a commons that we are all obligated to protect. North and South alike, as well as governments and industry, do have obligations to save the commons, if they are to share it. These species belong to us all.

\section{Planetary Home Economics}

The Costa Rica case points toward a new way of seeing the problems of economics and environment. Much of the tension in the discussion above arises from casting nation against nation, North against South; such international dispute is the legacy of centuries of politics between nation states. But if the issue is saving the Earth, this is domestic policy for us all. On global scales, no one has any foreign policy, because Earth is not a foreign country. If a particular action affects the Amazon, that is Brazilian domestic policy, but it is inseparable from the domestic policies of the other eight nations whose boundaries include the Rivers Amazon. And, since the Amazon drains nearly a quarter of all the freshwater runoff on Earth, and since the photosynthesis in the Amazon is significant on global scales, and since a disproportionate percentage of the Earth's biological richness is at stake there, what happens there is really domestic policy for Earthlings in the United States. The eleventh principle of international law, conserving environmental values, transcends the distinction between domestic and international law.

The oceans, the ozone layer, the atmosphere, the waters, landscapes, the heritage of biodiversity, the wildlife, species, germplasm lines, the health and integrity of the global environment- these are not values that people or nations should let themselves become rivals about because they are not particularly national or private resources. We need increasingly to think of these as world resources, even though nations and persons may sometimes, legitimately, control access to them. On global scales, nations are almost as ephemeral as persons. Whether by G-7 or G-77 nations, the common natural heritage is only temporarily to be appropriated as national property, under the constraint of its conservation for the good of the whole planet. In a fundamental sense, Earth, and its richness, is something that belongs to no one because it belongs to us all.

No one can avoid seeing Earth as the place where we must make a living, and we have to arrange economics on the planet so that all peoples have an opportunity to do that. This cannot be done without an equitable economic order, which is claimed in the eleventh principle. But Earth is also where we live, it is the home planet. We are natives, naturally born on Earth, before we are nationals, citizens of a political state, or managers, or laborers, owners of businesses or consumers in the markets. The human is first and always an Earthling.

The difficulty with making this view effective, of course, is that people have immediate needs, nearby business and community attachments, and they act on self-interested incentives, while their sense of global responsibility is weak. They must act locally, even if they think globally. The sense of collective responsibility is hard to build, but we do have it, to some degree, built up to national levels, and the challenge is to move it to global levels. 


\section{ETHICS AFTER THE EARTH SUMMIT}

Because everyone must make a living, we do have to think of Earth as a pie to be divided. Within limits we can produce more pie, as well as share it more equitably. But when we see Earth as the commons with a limited carrying capacity, the question of environmental protection remains inseparable from that of an equitable economic order. If forced to choose between the two, we might say that the question of the conservation of the planet is ultimate, the question of an equitable economic order only penultimate to that. In that sense, the eleventh principle reaches the ground of our being, the integrity of the planet, without which there can be no integrity in the social order.

A lesson that economists have learned in recent years is that economics is coupled with environment, and both with ethics. A lesson for environmentalists is this same coupling seen from the other end, that there is no environmental conservation without economic reform. The world is a complicated place and almost any analysis tends to oversimplify. All of our observations are true: there is asymmetry between rich and poor; there is both merit and exploitation; solutions need both justice and charity; we need both to produce and to share; resources are both natural and national resources, a common heritage and private property. There are these and a thousand more interconnections between environmental protection and an equitable international order.

We close with a summary observation, no doubt too simple, but now more true than ever before. The driving principles of international relations were formerly economics and national security. Since Rio, these two have become three: economics, environment, and security. For no nation, no people can be secure unless economics and environment are rationally coupled, and this on international, global scales. That is the first principle of planetary home economics.

Colorado State University

\section{Notes}

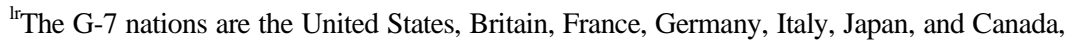
the largest nations in terms of industrial output. Some important small nations with high per capita wealth, though not among the seven, are best grouped with them, such as Sweden, Denmark, Norway, Switzerland. The eighth nation, interestingly, is Brazil, itself a study in contrasts, with the most skewed income distribution in the world and with enormous biodiversity at threat and in need of protection.

${ }^{2}$ In the Treaty of Tordesillas, 1494. The division becomes comically arrogant, when one remembers that, only two years after Columbus, their maps were so crude that they hardly knew where they were drawing what lines.

${ }^{3}$ There is nothing inherently unfair about importing or exporting, just because national boundaries are crossed. A good business deal can and ought to benefit both sides, no matter whether it is domestic or foreign.

${ }^{4}$ Main Committee Debate, June 4,1992, attended by Holmes Rolston. The debated text is in the draft working document for Agenda 21, UNCED Document A/CONF. 151.4 (part I), English text, Chapter 4, Sees. 4.3 and 4.5, page 27. At the insistence of the U.S., the final text contains more innocuous language. See UNCED 1992b, Agenda 21. 


\section{ROLSTON}

${ }^{5}$ Quoted in "Summit Organizers Hope the Sky's the Limit as Two Worlds Meet in Rio/* Denver Post, May 31, 1992, p. 17A, p. 24A. ${ }^{6}$ See note $4 .{ }^{7}$ Cited in Science, May 7, 1993, p. 735.

\section{Bibliography}

Allen, Frank Edward. 1992. "Earth Movers: Five Who Will Shape the Course of the Rio Conference." Wall Street Journal, May 29, p. A6.

Donaldson, Thomas. 1989. The Ethics of International Business. New York: Oxford University Press

Durning, Alan. 1992. How Much is Enough? The Consumer Society and the

Future of the Earth. New York: W. W. Norton.

Galbraith, John Kenneth. 1984. The Affluent Society, 4th ed. Boston: Houghton Mifflin. Jones, Dorothy V. 1991. Code of Peace: Ethics and Security in the World of Warlord States. Chicago: University of Chicago Press.

Kamm, Thomas. 1992. "Some Big Problems Await World Leaders at the Earth Summit." Wall Street Journal, May 29, p. Al, A6

Kamm, Thomas and Rose Gutfeld. 1992. "Rio Summit Kicks Off With Calls For More Aid to the Third World." Wall Street Journal, June 4.

Knickerbocker, Brad. 1992a. "World Leaders Gather at Rio for Earth Summit." Christian Science Monitor, June 2, p. 1, p. 4.

Knickerbocker, Brad. 1992b. "Summit Wrangles Over Money, North-South Split." Christian Science Monitor, June 4, p. 1, p. 4.

Knickerbocker, Brad. 1992c. "The World from Rio de Janeiro." Christian Science Monitor, June 10, p. 3.

Piel, Gerard. 1992. Only One World: Our Own to Make and to Keep. San Francisco: W. H. Freeman.

Shiva, Vandana. 1991. The Violence of the Green Revolution. London: Zed Books.

Stevens, William K. 1992. "Rio: A Start on Managing What's Left of This Place." New York Times, May 31, Sec. 4, p. 1

United Nations Conference on Environment and Development (UNCED). 1992a. Convention on Biological Diversity, 5 June.

United Nations Conference on Environment and Development (UNCED). 1992b. Agenda 21. Document No. A/CONK 151/26.

United Nations World Commission on Environment and Development. 1987a. Environmental Protection and Sustainable Development: Legal Principles and Recommendations. London/Dordrecht, Netherlands: Graham and Trotman/ Martinus Nijhoff Publishers.

United Nations World Commission on Environment and Development. 1987b. Our Common Future. Oxford: Oxford University Press. World Development Report 1991. New York: Oxford University Press. 